Indexed by

\title{
Scopus'
}

\section{PREDICTING THE COMMUTER'S WILLINGNESS TO USE LRT, UTILISING THE THEORY OF PLANNED BEHAVIOUR AND STRUCTURAL EQUATION}

\section{Hussain Dhafir Hussain}

Mustansiriyah University,

Department of Construction

and Project Management ,

Baghdad, Iraq

KOBSON

Key words: public transport, Urban Rail Development, TPB, SEM, Klang Valley doi:10.5937/jaes18-27013

Cite article:

Hussain, D. H. [2020]. Predicting the commuter's willingness to use Irt, utilising the theory of planned behaviour and structural equation. Journal of Applied Engineering Science, 18(3), 403 - 412

Online aceess of full paper is available at: www.engineeringscience.rs/browse-issues 


\title{
PREDICTING THE COMMUTER'S WILLINGNESS TO USE LRT, UTILISING THE THEORY OF PLANNED BEHAVIOUR AND STRUCTURAL EQUATION
}

\author{
Hussain Dhafir Hussain* \\ Mustansiriyah University, Department of Construction and Project Management, Baghdad, Iraq
}

Many researchers highlighted that the rail-based public transport system is not the people's favourite means of transportation in the Urban Rail Development Plan (2013) plus the Kuala Lumpur Structure Plan (2020). The policy-makers focused on this issue while planning the urban transportation system in Klang Valley, Malaysia. This region has undergone rapid growth in the past few years with regards to their geographical significance and population size. However, this increased traffic congestion in the city. In this study, the researcher has aimed to investigate and increase the accessibility of the commuters to and from their homes by the train systems in the Klang Valley.

For understanding the willingness of the people to use the train system in Klang Valley, the researcher studied 4 predictors, i.e., trust, situational factors, novelty-seeking and external influence, with respect to the Theory of Planned Behaviour (TPB) model. The researcher obtained the data from the people working in Klang Valley, Malaysia. The sample size used was 400 participants. The results indicated that the Perceived Behavioural Control (Pbc), attitude and subjective norm displayed positive effects on their behavioural intention to use the train system. Additionally, external influence and novelty-seeking positively affected the attitude. The 3 antecedents of trust, i.e., subjective norm, attitude and Pbc, indirectly and positively affected the intention of the commuters to use the train system. The situational factors showed an indirect, but bad influence on the intention of commuters to use trains, via the Pbc.

Key words: public transport, Urban Rail Development, TPB, SEM, Klang Valley

\section{INTRODUCTION}

In the past few years, many commuters, worldwide, have begun realising that the use of the train transit system is a convenient and dependable style of travelling within the urban cities. The rail transit services have received a lot of positive support due to their higher comfort level, safety, reliability and capacity [1]. Owing to these factors, the train commute is regarded as more favourable and has tremendously increased in reputation and popularity. Even though a great deal of promotion existed on using trains, one major challenge was the number of passengers using them. The expansion of private vehicle industries during the latter half of the $20^{\text {th }}$ Century saw a rapid decline in trains use.

Private cars have become the ultimate choice by most commuters to finish their daily bases travels in Malaysia and cities around the world. Recent studies exhibit that 6 million $(83 \%)$ of the trips accomplished by private cars however 1.24 million (17\% ) were accomplished by public transport in Klang valley, Malaysia [2, 3].Private vehicle employment is high in Malaysia in contrast to different cities for instance, London (10\%), Singapore (36\%), and Hong Kong (26\%) [3]. the dependence on private vehicle for most trips can cause critical situations, namely cars crashing, traffic jam and air pollution $[4,5]$. The best proposed solutions to minimize such dangerous outcome are using the bicycle, encourage commuters to park their cars and travel to the city by public transport or walking, minimize the number of private cars in every house [6]. A transportation system that have a beneficial economic, social as well as environmental outcome known as sustainable transport. Sustainable transport should meet each individual needs in term of providing efficient and affordable transport mode, at the same time boosting the economic development. It works on reducing waste and emissions and reduces pollution. In transport literature a number of researchers have been suggested for sustainable transport layout. Iftekhar and Tapsuwan [7] discussed the sustainable transport design as one of the factors affecting commuter's mode choice in Australia. Chen and Lu [6] discussed the affect of bike-sharing system commuter's attitude to come up with possible ways to encourage the commuters to use this system.

A dramatic increase in the geographical significance and population size has been noted in the Klang Valley, which has led to many traffic congestions, mostly during peak hours. Furthermore, the central business district in the town has rapidly developed, which has increased the number of car and motorcycle owners, which further increases traffic congestion on the roads or highways in and around the city.

The transport systems were seen to be a major factor that led to economic [8]. The transport infrastructure highlighted the developmental status of the city and it induced the growth of the existing city attractions and the creation of novel attractions [9]. The people select their mode of transport based on their trip purpose and 
the amount of travel time [10]. The train system attracts many travellers, who would have previously selected car travel, and offers many chances for faraway places which are very hard to accomplish using private cars. The reasons which encourage travellers to select the train commute however are still unclear. For investigating these factors, in this study, the researchers have applied the TPB model as their research framework and predicted the behavioural intention of the commuters to travel by train. The TPB model is seen to be a popular model that is used for predicting and explaining the people attitude and also can be used for much social behaviour having a strong predictive application [11, 12, 13, 14 and 15]. The additional constructs can further better the predictive power of the TPB [16]. Hence, the researchers have used the situational factors, like trust, novelty-seeking and external influence in the primary TPB theory.

\section{THEORY AND HYPOTHESES}

The TPB model has been used for explaining and predicting people attitude over many disciplines [17], like health, psychology, environment, education, technological applications, businesses, transportation and security. It was seen to be the extended version of the Theory of Reasoned Action (TRA), proposed by Fishbein and Ajzen [18].

It generalised the overall TRA model [19]. The Theory of Reasoned Action model states that the most vital determinant of the behaviour of a person was his intention to display behaviour. The intention of a person was the combination of his attitude and subjective norms. Furthermore, the approach towards the behaviour was seen to be the level to which the behavioural performance was negatively or positively valued. The subjective norms were explained as the comprehend pressure applied by the society to a person to participate or not in a specific behaviour category, as shown in Fig. 1. Fish bein and Ajzen [18] stated that when the behavioural intention was strong, the likelihood of the individual displaying a specific behaviour also increased. Ajzen [20] extended the TRA model to the TPB model by including another predictor which measured the Pbc. The PBC indicated the individual's awareness of his capacity to display a specific behaviour. The Pbc forecaster was directly associated with the individual's intention and behaviour.

The TPB model offered an acceptable framework for clarifying the motion manner since it included the main predictors for describing motion manner. The TPB also included additional predictors for growing the power of prediction of the model. The different constructs used in the TPB help in examining the relationship between the situational factors, trust, $\mathrm{Pbc}$, subjective norms, external influence and novelty-seeking, with regards to the commuters' intention to use the public transport system.

Here, the TPB model indicated that the person was very likely to use the public transport system rather than any other mode of travel if he/she displayed a positive attitude towards the use of public transport. Some people were also influenced by the opinions expressed by their friends, family or colleagues concerning the utilization of public transport systems and also possessed the necessary resources, ability and opportunities to use this system. Hence, the researchers summarised the earlier discussions and presented their hypotheses as follows:

- Hypothesis 1: "The attitude was positively associated with the intention of the people to use the train system".

- Hypothesis 2: "Subjective norm was positively associated with the intention of the people to use the train system".

- Hypothesis 3: "Perceived behavioural control was positively associated with the intention of the people to use the train system".

Situational predictor factors refer to the physical factor which facilitates or inhibits the behaviour [21]. Here, the

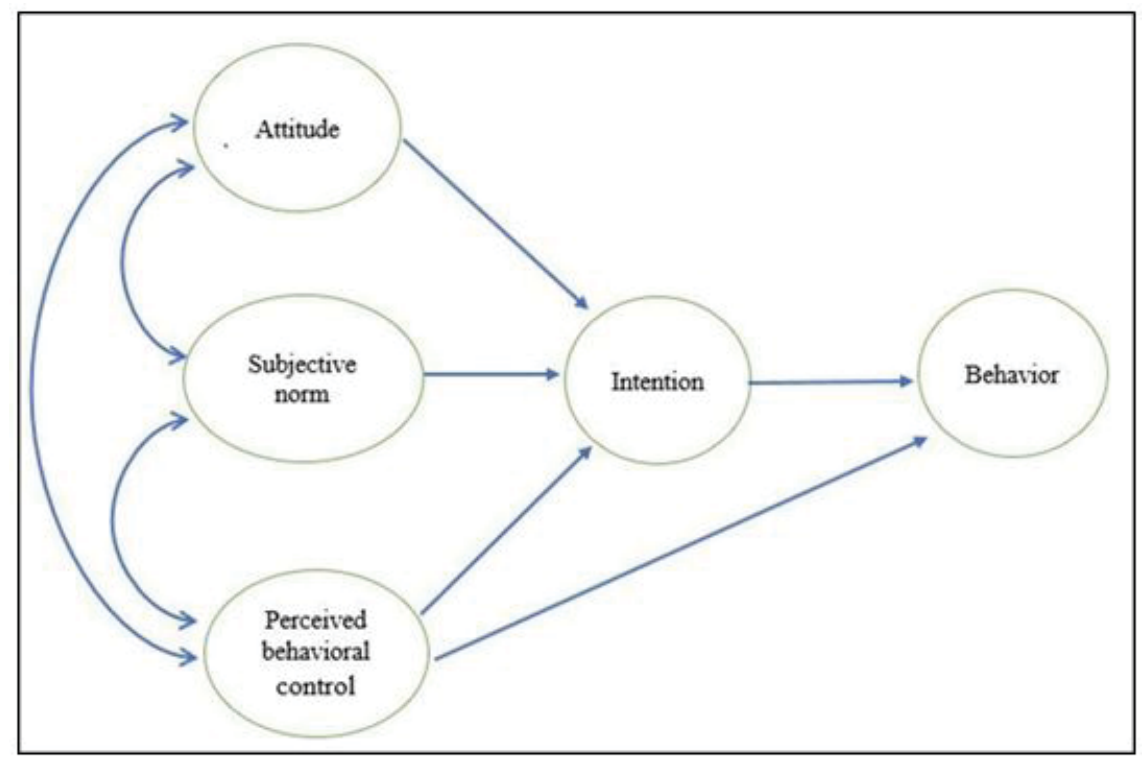

Figure 1: TBP (Theory of planned behaviour) 
situation predictors included the factors which could promote or prevent the use of the public transport system. The people display a positive attitude towards the use of public transport systems for decreasing the traffic congestion and pollution that was caused by cars. However, this did not indicate that they willingly used public transit systems in actual scenarios. Many factors prevented the use of public transport systems like availability of free parking at their workplace, limited transport routes which were controlled by the public transport systems, a prolonged travel time required by the public transport systems and remote location of the transport stations. Hence, the researchers proposed another hypothesis as follows:

- Hypothesis 4: "Situation Factors were negatively associated with the Perceived Behavioural Control".

Consumer trust was classified as the expectation of the customer that the service supplier was reliable and could be depended on to supply his promise. For ensuring trust, the consumers need to believe that the trustee was motivated and capable of delivering the expected quality of the services and goods [22]. Trust is defined as a particular belief, which influences the behavioural intention and the antecedents of intention. Trust played a vital part in inspecting the tangible behaviour of the customer [23, 24].

Hsiao and Yang [25] extended the TPB model and investigated the usage of high-speed trains amongst the Taiwanese pupils. They linked the trust to the students' intention behaviour based on factors like subjective norms, attitude, and $\mathrm{Pbc}$. To understand the relationship concerning the antecedents of intention and the belief structures, the researchers proposed the following hypotheses:

- Hypothesis 5: "Trust was positively associated with the students' attitude towards taking the train".

- Hypothesis 6: "Trust is positively associated with the students' attitude towards taking the train".

- Hypothesis 7: "Trust is positively associated with the students' attitude towards taking the train".

Novelty-seeking was seen to be an explanatory or curiosity drive that could influence the consumers' attitude towards the choice of their travel destination and technological products [26]. In their study, Hsiao and Yang [25] presumed that while making decisions regarding the selection of the mode of transport, the tourists, who displayed a higher propensity for novel seeking, showed a highly positive attitude towards the choice of a new mode of transport. Hence, the researchers hypothesised that:

- Hypothesis 8: Novelty-seeking was positively associated with the commuters' attitude towards taking train.

The subjective norms showed a higher interpersonal influence of the colleagues, friends and family on the commuters whereas external influence indicated the effect of skilled ideas, press statements, and numerous private info which was deliberated by the commuters before displaying a behaviour. In their study, Bhattacherjee noted that the external influence was a significant predictor of the subjective norms [27]. Based on these factors, the researchers hypothesised that:

- Hypothesis 9: "External Influence was positively associated with the commuters' attitude towards taking the train".

\section{AIMS OF THIS STUDY}

The researchers used the TPB model to illustrate the commuter's ability to use a train. They expected that the commuters were more willing to travel by train if they displayed a positive attitude regarding their behaviour, expected their family, colleagues and friends to approve of their behaviour, and they believed that they possessed proper resources like money or time for undertaking their behaviour. The prime goal is to persuade commuters to use urban rail .Additionally, the researchers suggested that 4 more constructs -trust, novelty-seeking, situational factors, and external influence, could influence the willingness of the commuters to use the train system.

\section{METHODOLOGY}

The data collection technique that was used by the researchers included the distribution of questionnaires amongst the respondents in the commercial and residential regions in Klang Valley, along with the local companies. These questionnaires were distributed in 4 well-known areas with a higher rate of traffic congestion (north - east - west - south areas). About 100 questionnaires were distributed after conducting one on one interview with random respondents (above the age of 18). This was believed to be the most effective technique with regards to its informational accuracy; however, it was not very popular due to a deficiency in manpower and time. 200 additional copies of these questionnaires were put in the post-boxes of the inhabitants and were later collected from the administration offices. However, owing to the lack of any valuable data, not all of them were included in this study. Furthermore, after carrying out discussions with the administrations of local companies, 200 copies of the questionnaire were submitted to the company administration and were retrieved after some days. All data was retrieved within 3 months. Thus, out of the total 400-500 distributed questionnaires, only 400 were used in this study.

The researchers formed a pilot study including 50 subjects for testing the effectiveness of the initial copy of this survey. Based on the feedback, a few alterations were carried out in the questionnaires, before they were disseminated to the respondents. An example of the questionnaire used in the study has been presented in Appendix A. The preference data was gathered for determining the socioeconomic characteristics of the commuters. This socioeconomic data comprised the age, income, gender, vehicle ownership, household 
size and the education level of the respondents. The researchers measured 8 constructs related to the TPB model. The initial scale factors were selected from the previously-validated measures; however, they were rewritten to suit this study. The items were assessed by means of the 5-Point Likert scale, which ranged between $1=$ "Strongly Disagree" and $5=$ "Strongly Agree". The value of 3 indicated a "neutral" or "not sure" response. The behavioural intention was determined using the 4 -item scale used in earlier studies [28, 29, 27]. The factors of subjective norm, attitude and $\mathrm{Pbc}$, adapted in Taylor \& Todd [29] were used in this study. Trust and situational factors were measured using the scales adapted earlier [11]. The novelty-seeking factor was also modified from earlier studies $[30,25]$. The external influence factor was a variant of that used by Bhattacherjee [27] and fulfilled the broad area of the constructs.

Table 1 presents the socio-economic, demographic and travel-related characteristics of all the respondents. The quantity of male respondents " $52.7 \%$ " was greater than female respondents "47.3\%". Most of the respondents were aged from 26 to 36 years $38.1 \%$, while $62.7 \%$ of respondents possessed a college degree. The monthly income of a majority of the respondents was >RM 5000 $57.2 \%$. These characteristics were similar to the official statistical data, i.e., $51 \%$ males and $49 \%$ females. $37 \%$ of the total population was aged between 26 and 36 years, while $32 \%$ of the population was aged between 37 and 54 years [31]. About $77.3 \%$ of the population possessed a college degree, while $7.5 \%$ had a post-graduate degree [32].

\section{RESULTS AND DISCUSSION}

In order to develop the SEM model that was used in the study, the researchers applied 2 approaches (i.e., measurement and structural model), which were recommended earlier [33, 34, 35]. These models were used for assessing the model appropriateness and construct legitimacy, along with testing the hypotheses.

\section{Measurement model}

In Step 1, the researchers replicated the primary TPB model utilizing the gathered data in this study. After the model was developed, the results indicated acceptable goodness of fit indices. The Relative Chi-squared value $\left(X^{2} / d f\right)$ of 1.822 was noted, while the values of other indices were: "GFI $=0.94$; AGFI $=0.92$ : $\mathrm{TLI}=0.97$ : $\mathrm{CFI}=0.98$ : RMR $=0.05$; RMSEA $=0.045 "$. The suitability of the fit indices was noted in Table 2.

In Step 2, they developed the SEM measurement model and then validated it. The researchers used the Confirmatory Factor Analysis (CFA) technique for adding or removing items in the constructs which had a loading

Table 2: Appropriateness of the fit indices (Measurement model)

\begin{tabular}{|c|c|c|}
\hline $\begin{array}{c}\text { Suitability } \\
\text { Index }\end{array}$ & $\begin{array}{c}\text { Original Theory of } \\
\text { Planned Behaviour (TPB) }\end{array}$ & $\begin{array}{c}\text { Standard } \\
\text { Value }\end{array}$ \\
\hline $\mathbf{X}^{2} / \mathrm{df}$ & 1.822 & $2-5$ \\
\hline GFI & 0.94 & $\geq 0.9$ \\
\hline AGFI & 0.92 & $\geq 0.9$ \\
\hline TLI & 0.97 & $\geq 0.95$ \\
\hline CFI & 0.98 & $\geq 0.95$ \\
\hline RMR & 0.05 & $<1$ \\
\hline RMSEA & 0.045 & $<0.08$ \\
\hline
\end{tabular}

Table 1: Personal information

\begin{tabular}{|c|c|c|c|}
\hline \multirow{2}{*}{\multicolumn{2}{|c|}{ ATTRIBUTES }} & \multicolumn{2}{c|}{$\%$} \\
\cline { 3 - 4 } & & Research Data & Department of Statistics Data \\
\hline \multirow{4}{*}{ Age } & $18-25$ & 15.6 & 16.9 \\
\cline { 2 - 4 } & $26-36$ & 38.1 & 37.6 \\
\cline { 2 - 4 } & $37-54$ & 34.5 & 32.4 \\
\cline { 2 - 4 } & 55 and more & 11.8 & 13.1 \\
\hline \multirow{2}{*}{ Gender } & Male & 52.7 & 51 \\
\cline { 2 - 4 } & Female & 47.3 & 49 \\
\hline \multirow{3}{*}{$\begin{array}{c}\text { Level of } \\
\text { Education }\end{array}$} & School & 20.1 & 15.2 \\
\cline { 2 - 4 } & College & 62.7 & 77.3 \\
\hline \multirow{2}{*}{ Income } & $\begin{array}{c}\text { Lest-graduation } \\
\text { Transport } \\
\text { choice }\end{array}$ & 17.2 & 7.5 \\
\cline { 2 - 4 } & than 5000 rm More & 42.8 & 43.4 \\
\cline { 2 - 4 } & Car & 57.2 & 56.6 \\
\cline { 2 - 4 } & Bus & 61.6 & \multirow{2}{*}{ Unavailable } \\
\hline
\end{tabular}


factor that was $<0.5$ or insignificant $[34,36,25,37]$. This examination is used for assessing the dependability of all items and constructs. Table 3 showed the goodnessof-fit indices for the CFA, which showed a satisfactory fit of this measurement model. The value for the Relative Chi-squared factor $\left(X^{2} / d f\right)$ was 1.642 , while the values of the other fit indices were: "GFI $=0.90$; $A G F I=0.89$; $\mathrm{CFI}=0.97 ; \mathrm{TLI}=0.96 ; \mathrm{RMR}=0.049 ; \mathrm{RMSEA}=0.047 "$.
For validating the measurement model, the researchers used 3 forms of validity metrics, i.e., convergent validity, discriminant validity and content validity. The content validity was noted by ensuring the consistency between all measurement items and earlier studies. The convergent validity was assessed by determining the Composite Reliability (CR) and the Average Variance Extracted (AVE) from all measures (Hair et al., 1998). Table 3 presents

Table 3: Values for the standardised loadings and reliability

\begin{tabular}{|c|c|c|c|c|}
\hline items & loading factor & CR & average variances extracted & cronbach's alpha \\
\hline IN. & & 0.852 & 0.633 & 0.851 \\
\hline IN 1 & 0.721 & & & \\
\hline IN 2 & 0.975 & & & \\
\hline IN 3 & 0.803 & & & \\
\hline IN 4 & 0.622 & & & \\
\hline Attitude & & 0.902 & 0.601 & 0.905 \\
\hline At 1 & 0.702 & & & \\
\hline At 2 & 0.921 & & & \\
\hline At 3 & 0.935 & & & \\
\hline At 4 & 0.980 & & & \\
\hline At 5 & 0.773 & & & \\
\hline At 6 & 0.601 & & & \\
\hline At 7 & DROP & & & \\
\hline Situational factors & & 0.820 & 0.651 & 0.815 \\
\hline Sf 1 & 0.592 & & & \\
\hline Sf 2 & 0.854 & & & \\
\hline Sf 3 & 0.505 & & & \\
\hline Sf 4 & 0.686 & & & \\
\hline Sf 5 & 0.698 & & & \\
\hline Subjective norms & & 0.805 & 0.612 & 0.802 \\
\hline Sn 1 & 0.807 & & & \\
\hline Sn 2 & 0.874 & & & \\
\hline Sn 3 & 0.699 & & & \\
\hline Perceived behaviour control & & 0.874 & 0.535 & 0.863 \\
\hline \begin{tabular}{r|} 
Pbc 1 \\
\end{tabular} & 0.800 & & & \\
\hline Pbc 2 & 0.847 & & & \\
\hline Pbc 3 & 0.812 & & & \\
\hline Pbc 4 & 0.614 & & & \\
\hline Pbc 5 & 0.633 & & & \\
\hline Pbc 6 & 0.598 & & & \\
\hline Novelty-seeking & & 0.923 & 0.744 & 0.918 \\
\hline Ns 1 & 0.934 & & & \\
\hline Ns 2 & 0.856 & & & \\
\hline Ns 3 & 0.845 & & & \\
\hline Ns 4 & 0.755 & & & \\
\hline Trust & & 0.951 & 0.675 & 0.953 \\
\hline $\operatorname{Tr} 1$ & DROP & & & \\
\hline $\operatorname{Tr} 2$ & 0.711 & & & \\
\hline $\operatorname{Tr} 3$ & DROP & & & \\
\hline $\operatorname{Tr} 4$ & 0.884 & & & \\
\hline $\operatorname{Tr} 5$ & 0.747 & & & \\
\hline $\operatorname{Tr} 6$ & 0.776 & & & \\
\hline $\operatorname{Tr} 7$ & 0.916 & & & \\
\hline $\operatorname{Tr} 8$ & 0.795 & & & \\
\hline $\operatorname{Tr} 9$ & 0.803 & & & \\
\hline External influence & & 0.795 & 0.563 & 0.786 \\
\hline Ei 1 & 0.758 & & & \\
\hline Ei 2 & 0.846 & & & \\
\hline Ei 3 & 0.709 & & & \\
\hline
\end{tabular}


the values of the $\mathrm{CR}$ noted in this study which ranged between 0.795 and 0.951 . The values surpassed the suggested threshold value of 0.50 [34]. The AVE value also ranged between "0.535 and 0.744 "; which was higher than the accepted value of 0.50 . Table 3 presents the values of the loadings for the measures used in this study. The different paths used in this measurement model had a loading factor $>0.5$.

Table 4 presents the values of the inter correlation for the variables. Results indicated a substantial correlation amongst the behavioural intention and all other constructs.

The cause-squared AVE value for every construct must be higher than the correlation between all the constructs [38]. The AVE value would be squared at the source and compared to the correlation value for all constructs. The researchers analysed the cause-squared AVE values for the constructs like attitude, intention, subjective norms, $\mathrm{Pbc}$, situational factors, trust, novelty-seeking and external influence; and noted that the values for the measurement model were higher than the correlation values for the constructs, as presented in Table 4. This indicated a high source-squared AVE value compared to the correlation amongst the constructs. Thus, it was concluded that discriminant validity fulfilled all conditions. Table 4 summarised the discriminant validity values for this measurement model.

\section{Structural Model}

The researchers modified the measurement model and developed a new model for testing and examining the relationship structure which was shown in the theoretical model used in the study. Fig. 2 presents this model construct which was founded on the analytical results of the study.

The researchers used the AMOS 20 software for evaluating the model appropriateness and path of all recommended hypotheses. Results indicated that most of the fit indices showed satisfactory values " $\mathrm{X}^{2} / \mathrm{df}=1.598$; $\mathrm{TLI}=0.94 ; \mathrm{GFI}=0.87 ; \mathrm{AGFI}=0.86 ; \mathrm{CFI}=0.96$; RMR = 0.081; RMSEA = 0.045". Gefen et al. (2003) stated that the value of the GFI could be increased by eliminating the items with a small factor loading [22]. After dropping some items with a smaller factor loading, the GFI was increased to the acceptable value of 0.9 . Table 5 shows the other fit indices also increased " $\mathrm{X}^{2} / \mathrm{df}=1.657 ; \mathrm{TLI}=0.96 ; \mathrm{GFI}=0.91 ; \mathrm{AGFI}=0.9$; $\mathrm{CFI}=0.97 ; \mathrm{RMR}=0.08 ; \mathrm{RMSEA}=0.05 "$.

Table 4: Correlation noted between all formats

\begin{tabular}{|c|c|c|c|c|c|c|c|c|}
\hline & $\begin{array}{c}\text { Inten- } \\
\text { tion }\end{array}$ & $\begin{array}{c}\text { Atti- } \\
\text { tude }\end{array}$ & $\begin{array}{c}\text { Situation- } \\
\text { al factors }\end{array}$ & $\begin{array}{c}\text { Subjective } \\
\text { norms }\end{array}$ & $\begin{array}{c}\text { Perceived } \\
\text { behaviour } \\
\text { control }\end{array}$ & Novelty-seeking & Trust & $\begin{array}{c}\text { External } \\
\text { influence }\end{array}$ \\
\hline Intention & $\mathbf{0 . 7 8 3}$ & & & & & & & \\
\hline Attitude & 0.413 & $\mathbf{0 . 7 7 2}$ & & & & & & \\
\hline Situational factors & 0.052 & -0.287 & $\mathbf{0 . 7 9 4}$ & & & & & \\
\hline Subjective norms & 0.301 & 0.159 & -0.069 & $\mathbf{0 . 7 5 5}$ & & & & \\
\hline $\begin{array}{c}\text { Perceived } \\
\text { behaviour control }\end{array}$ & 0.274 & 0.179 & -0.231 & 0.165 & $\mathbf{0 . 7 1 9}$ & & & \\
\hline Novelty-seeking & 0.205 & 0.27 & -0.107 & 0.212 & 0.147 & $\mathbf{0 . 8 6}$ & & \\
\hline Trust & 0.145 & 0.318 & -0.149 & 0.238 & 0.216 & 0.256 & $\mathbf{0 . 8 1}$ & \\
\hline External influence & 0.198 & 0.256 & -0.163 & 0.207 & 0.116 & 0.125 & 0.177 & $\mathbf{0 . 7 3 3}$ \\
\hline
\end{tabular}



Figure 2: The research model used in the study 
Table 5: The appropriateness of the Fit Indices for the Structural Model

\begin{tabular}{|c|c|c|c|c|c|c|c|}
\hline Suitability Index & $\mathrm{X}^{2}$ Idf & GFI & AGFI & TLI & CFI & RMR & RMSEA \\
\hline $\begin{array}{c}\text { Modified Theory } \\
\text { of Planned Be- } \\
\text { haviour Model } \\
\text { (Structural) }\end{array}$ & 1.657 & 0.91 & 0.9 & 0.96 & 0.97 & 0.08 & 0.05 \\
\hline Standard Value & $2-5$ & $\geq 0.9$ & $\geq 0.9$ & $\geq 0.95$ & $\geq 0.95$ & $<1$ & $<0.08$ \\
\hline
\end{tabular}

Table 6 presents a summary of all fit indices noted in the structural model. In many studies that used the SEM, the models did not display higher appropriateness for the indices [39, 40].

In this study, the researchers identified that all fit indices used in the structural model were either equal or lesser than those seen in the primary TPB model used previously. This could be because of the additional parameters since a growth in the quantity of parameters to be assessed led to a higher loss in the degree of freedom. Thus, a model having 0 degrees of freedom indicated the best fit (the value of CFI would be 1; RMSEA = 0; Chi-square $=0$; etc.). As a majority of these fit indices were acceptable, the researcher has used this modified model since it suited this case study.

After establishing the measurement model, the researchers used the SEM technique for determining the causal structure of the model proposed in the study. They examined the standardised path coefficients and noted that the paths were significant at the 0.01 levels except a few which were significant at values $<0.05$. Thus, all the paths were seen to be significant and expected. The Hypotheses 1 to 3 were supported since many studies presumed them and applied the TPB for explaining the behavioural intention. It was noted that factors like subjective norm "b $=0.191, p<0.001 "$, attitude "b $=0.198$, $p<0.001 "$ and Pbc "b $=0.199, p<0.01 "$ positively influenced the behavioural intention of the commuters to use the public transport system in the Klang Valley. Furthermore, the situational factors showed a significantly negative effect on the $\mathrm{Pbc}$ of the respondents and their behavioural intention to make use of the city train system. The results supported Hypothesis 4. The situation factors "b $=-0.154, p<0.01 "$ were observed to be a negative influence, which prevented the commuters from taking the train. The results indicated that the trust showed an indirect and significant effect on the intention of the students to use the train, based on the factors like subjective norm "b $=0.218, p<0.001 "$, attitude "b = 0.267, $p<0.001 "$, and $\mathrm{Pbc} " \mathrm{~b}=0.145, \mathrm{p}<0.01 "$ ". Furthermore, Hypothesis 8 was also supported "b $=0.243 ; p<0.01$ ", which indicated that novelty-seeking was an antecedent of the attitude. Hypothesis 9 could be supported "b $=0.257$; $p<0.01$ ", which indicated that the exterior influence was the significant predictor of the attitude.

\section{CONCLUSIONS}

In this present study, the researchers have emphasised the issues that could affect the method of travel used by the commuters in the Klang Valley by applying and extending the TPB model [17]. The research model used in this study was supported and all the hypotheses were confirmed.

The results indicated that a favourable attitude towards the use of the train system showed the highest effect on the behavioural intention of the commuters out of the 3 factors studied. Thus, it was concluded that the Majlis Bandaraya Klang Valley could attract many riders if they displayed a positive disposition about themselves. Also, the Pbc showed a higher effect. Hence, convenient access and low fares could enhance the decision of the commuters to use the train. Finally, subjective norms showed the lowest effect on the intention of the commuters as noted in many studies [41, 28]. A weaker influence of the subjective norms indicated that in a domestic market, the travellers could select independent decisions

Table 6: A summary of suitability

\begin{tabular}{|c|c|c|c|c|c|c|c|}
\hline Suitability Index & $\mathbf{X}^{2}$ Iff & GFI & AGFI & TLI & CFI & RMR & RMSEA \\
\hline $\begin{array}{c}\text { Original Theory of Planned } \\
\text { Behaviour (TPB) }\end{array}$ & 1.822 & 0.94 & 0.92 & 0.97 & 0.98 & 0.05 & 0.045 \\
\hline $\begin{array}{c}\text { Modified Theory of Planned } \\
\text { Behaviour Model (Structural) }\end{array}$ & 1.657 & 0.91 & 0.9 & 0.96 & 0.97 & 0.08 & 0.05 \\
\hline Standard Value & $2-5$ & $\geq 0.9$ & $\geq 0.9$ & $\geq 0.95$ & $\geq 0.95$ & $<1$ & $<0.08$ \\
\hline
\end{tabular}


while planning their leisure activities, with a lesser need to consult their friends and family.

TPB model is hired in which the result shows a fair goodness of fit indices. The Relative Chi-squared value $\left(x^{2} / \mathrm{df}\right)$ of 1.822 was identified, while the values of other indices were: $\mathrm{GFI}=0.94$; $\mathrm{AGFI}=0.92$ : $\mathrm{TLI}=0.97$ : $\mathrm{CFI}=0.98$ : RMR $=0.05$; RMSEA = 0.045". Structural model also has been utilized. The Relative Chi-squared value $(x 2 / d f)=$ 1.657; $\mathrm{TLI}=0.96 ; \mathrm{GFI}=0.91 ; \mathrm{AGFI}=0.9 ; \mathrm{CFI}=0.97$; $\mathrm{RMR}=0.08$; RMSEA $=0.05 "$.

For validation purpose 3 forms of validity metrics is used, i.e., convergent validity, discriminant validity and content validity. The content validity was identified by guarantee the consistency between all measurement items and previous studies. The convergent validity was identified by locating the Composite Reliability (CR) and the Average Variance Extracted (AVE) from all measures. The values of the CR noted in this study which ranged between 0.795 and 0.951 . The values exceeded the submitted threshold value of 0.50 . The AVE value also ranged between "0.535 and 0.744 "; which was higher than the accepted value of 0.50 . The loading factor was> 0.5 for all the paths.

The researchers examined the standardized path coefficients and noted that the paths were significant at the 0.01 levels, however a few were significant at values $<0.05$. Overall, the paths were significant and expected.

The results indicate that trust could secondarily affect the intent of the commuters to use the train based on factors like subjective norms, attitude and $\mathrm{Pbc}$. It was concluded that the lower intention of the commuters to use the train system was due to their unfavourable attitude to the train system, which was influenced by trust in the system. Trust was seen to be as important in improving the customer attitude as the novelty-seeking since safety and reliability were the vital traits which were sought by the passengers during their train travel. Berry [42] stated that trust was the primary basis for faithfulness. The Majlis Klang Valley could display a favourable attitude towards the train travel by presenting a dependable brand image. For this purpose, the Majlis Klang Valley must exhibit its management and maintenance ability. They should also provide comfortable seating and high service quality, as discussed in earlier studies [43] since these factors could improve the travel conditions. These factors played a major role while planning work-related trips since public transport was a competitive alternative for the use of cars.

Results indicated that the novelty-seeking and external influence affected the commuter intention to use the trains in an indirect manner via the attitude. Novelty-seeking was a natural motivator for seeking new stimuli, products and experiences [25]. A lower intention to use the train was significantly swayed by the inclination of the commuters for novelty-seeking. Hence, promoting new incentives and new trip experiences could make the train travel more favourable, thereby increasing their will to use this mode of transport. The external influence was based on the advertisements generated by offline or online media along with promotional offers. The external influence affected the commuters' attitude towards train use.

Some limitations are seen in this study. Firstly, the researchers presented 2 factors affecting the novelty-seeking, i.e., the new users would find the train usage an exciting and novel experience since many Malaysians did not feel the need to use a train system in the past. Furthermore, regular train travellers would not entertain train travel as an exhilarating experience. The researchers recommended that in future, the studies need to incorporate other vital factors like security, comfort, dependability, reliability, accessibility and time or budget restrictions for deriving an accurate result. After counting the above-mentioned variables, a fitted model could be acquired.

The researchers used the TPB model and made very important observations attached to the behavioural intention of the commuters to use the train system in the Klang Valley. Results indicated a relatively good predictive validity. However, in future, they recommended the use of alternative models or a multi-aspect approach for understanding all the factors affecting the mode of travel preferred by the commuter. The future studies also need to determine if the past behaviour acted as the mediator which affected the causal relationships between the loyalty or behavioural intention and antecedents when many travellers experience a train journey. Also, a few personal features should be tested for understanding their effect.

\section{ACKNOWLEDGEMENT}

The author would like to thank Mustansiriyah University, Baghdad - Iraq for its support in the present work.

\section{REFERENCES}

1. Koting, S. B. (2017). Evaluation and Improvement of Accessibility To Urban Rail Transit System in Faculty of Engineering. http://studentsrepo.um.edu. my/7795/6/PhD_Thesis_Final_15082017_Suhana_ Koting.pdf.

2. Chen, S.; Sutan, R. and Hisham, J. (2018). Trip characteristics as the determinants of intention to shift to rail transport among private motor vehicle users in Kuala Lumpur, Malaysia. Sustainable Cities and Society, 36(October 2017), 319-326. https://doi. org/10.1016/j.scs.2017.10.030.

3. Chuen, C. O.; Karim, M. R.; and Yusoff, S. (2014). Mode choice between private and public transport in Klang Valley, Malaysia. The Scientific World Journal, 2014(Figure 1), 7-9. https://doi. org/10.1155/2014/394587. 
4. Borhan, M. N.; Ibrahim, A. N. H.; Syamsunur, D.; and Rahmat, R. A.. (2019). Why Public Bus is a Less Attractive Mode of Transport: A Case Study of Putrajaya, Malaysia. Periodica Polytechnica Transportation Engineering, 47(1), 82-90. file:///C:/Users/ lenovo/Downloads/9228-Article Text PDF-30469-310-20181214.pdf.

5. Meek, S.; Ison, S.; and Enoch, M. (2011). Evaluating alternative concepts of bus-based park and ride. Transport Policy, 18(2), 456-467. https://doi. org/10.1016/j.tranpol.2010.09.006.

6. Chen, S. Y.; and Lu, C. C. (2016). A Model of Green Acceptance and Intentions to Use Bike-Sharing: You Bike Users in Taiwan. Networks and Spatial Economics, 16(4), 1103-1124. https://doi.org/10.1007/ s11067-015-9312-8.

7. Iftekhar, S.; and Tapsuwan, S. (2010). Review of transportation choice research in Australia: Implications for sustainable urban transport design. Natural Resources Forum, 34(4), 255-265. https://doi. org/10.1111/j.1477-8947.2010.01310.x.

8. Jacyna, M.; Wasiak, M.; Lewczuk, K.; and Kłodawski, M. (2014). Simulation model of transport system of Poland as a tool for developing sustainable transport. Archives of Transport, 31(3), 23-35. https://doi. org/10.5604/08669546.1146982.

9. Skorobogatova, O.; and Kuzmina-Merlino, I. (2017). Transport Infrastructure Development Performance. Procedia Engineering, 178, 319-329. https://doi. org/10.1016/j.proeng.2017.01.056.

10. Yang, J.; and Ma, J. (2019). Compressive sensing-enhanced feature selection and its application in travel mode choice prediction. Applied Soft Computing Journal, 75, 537-547. https://doi.org/10.1016/j. asoc.2018.10.048.

11. Borhan, M. N. (2013). The Effectiveness of Public Transport System in Putrajaya: A Modelling Approach. Universiti Kebangsaan Malaysia.

12. Chan, L.; and Bishop, B. (2013). A moral basis for recycling: Extending the theory of planned behaviour. Journal of Environmental Psychology, 36, 96-102. https://doi.org/10.1016/j.jenvp.2013.07.010.

13. Donald, I. J.; Cooper, S. R.; and Conchie, S. M. (2014). An extended theory of planned behaviour model of the psychological factors affecting commuters' transport mode use. Journal of Environmental Psychology, 40, 39-48. https://doi.org/10.1016/j.jenvp.2014.03.003.

14. Jing, P.; Huang, H.; Ran, B.; Zhan, F.; and Shi, Y. (2019). Exploring the factors affecting mode choice intention of autonomous vehicle based on an extended theory of planned behavior-A case study in China. Sustainability (Switzerland), 11(4), 1-20. https://doi.org/10.3390/su11041155.
15. Li, S.; Zhao, P.; Zhang, H.; and Quan, J. (2019). Walking behavior in the old downtown Beijing: The impact of perceptions and attitudes and social variations. Transport Policy, 73, 1-11. https://doi.org/10.1016/j. tranpol.2018.10.005.

16. Conner, M.; and Abraham, C. (2001). Conscientiousness and the theory of planned behavior: Toward a more complete model of the antecedents of intentions and behavior. Personality and Social Psychology Bulletin, 27(11), 1547-1561. https://doi. org/10.1177/01461672012711014.

17. Ajzen, Icek (1991). The theory of planned behavior. Organizational Behavior and Human Decision Processes, 50(2), 179-211. https://doi. org/10.1016/0749-5978(91)90020-T.

18. Fishbein, M.; and Ajzen, I. (1975). Belief, attitude, intention and behavior: An introduction to theory and research. Reading. MA: Addison-Wesley series in social psychology. http://people.umass.edu/ aizen/f\&a1975.html.

19. Ajzen, I; and Fishbein, M. (1980). Understanding attitudes and predicting social behaviour. http://www. citeulike.org/group/38/article/235626.

20. Ajzen, Icek. (1985). From intentions to actions: A theory of planned behavior. Action Control, Springer, 11-39. https://link.springer.com/chapter/10.1007/978-3-642-69746-3_2.

21. Mahmud, S. N. D.; and Osman, K. (2010). The determinants of recycling intention behavior among the Malaysian school students: An application of Theory of Planned Behaviour. Procedia - Social and Behavioral Sciences, 9, 119-124. https://doi.org/10.1016/j. sbspro.2010.12.123.

22. Gefen, D.; Karahanna, E.; and Straub, D. (2003). Trust and TAM in online shopping: An integrated model. MIS Quarterly, 27(1), 51-90. http://www.jstor. org/stable/30036519.\%0D.

23. Akroush, M. N.; and Al-Debei, M. M. (2015). An integrated model of factors affecting consumer attitudes towards online shopping. Business Process Management Journal, 21(6), 1353-1376. https://doi. org/10.1108/BPMJ-02-2015-0022.

24. Abdul Rehman, C.; Bin Dost, M. K.; and Illyas, M. (2015). Online Shopping Trends and Its Effects on Consumer Buying Behavior: A Case Study of Young Generation of Pakistan. NG-Journal of Social Development, 5(1), 1-22. https://doi. org/10.12816/0032077.

25. Hsiao, C. H.; and Yang, C. (2010). Predicting the travel intention to take High Speed Rail among college students. Transportation Research Part F: Traffic Psychology and Behaviour, 13(4), 277-287. https://doi.org/10.1016/j.trf.2010.04.011. 
26. (Shawn) Jang, S. C.; and Feng, R. (2007). Temporal destination revisit intention: The effects of novelty seeking and satisfaction. Tourism Management, 28(2), 580-590. https://doi.org/10.1016/j.tourman.2006.04.024.

27. Bhattacherjee, A. (2000). Acceptance of e-Commerce Services: The Case of Electronic Brokerages. Systems, Man and Cybernetics, Part A: Systems and Humans, IEEE Transactions on, 30(4), 411-420.

28. Ajzen, Icek; and Driver, B. L. (1992). Application of the Theory of Planned Behavior to Leisure Choice. Journal of Leisure Research, 24(3), 207-224. https:// doi.org/10.1080/00222216.1992.11969889.

29. Taylor, S.; and Todd, P. A. (1995). Understanding information technology usage.pdf.crdownload.pdf. In Information Systems Research (Vol. 6, Issue 2, pp. 144-176). https://doi.org/10.1287/isre.6.2.144.

30. Lee, T. H.; and Crompton, J. (1992). Measuring novelty seeking in tourism. Annals of Tourism Research, 19(4), 732-751. https://doi.org/10.1016/01607383(92)90064-V.

31. DOS. (2012). Department of statistics.

32. DOS. (2008). Department of statistics.

33. Anderson, J. C.; and Gerbing, D. W. (1988). Structural equation modeling in practice: A review and recommended two-step approach. Psychological Bulletin, 103(3), 411-423. http://psycnet.apa.org/ psycinfo/1989-14190-001.

34. Hair, J.F. JR.; Anderson, R.E.; Tatham, R.L.; and Black, W. C. (1998). Multivariate Data Analysis, (5th Editio).

35. Jackson, J.L.; Dezee, K.; Douglas, K.; and Shimeall, W. (2005). Introduction to Structural Equation Modelling (Path Analysis). Society of General Internal Medicine (SGIM).

36. Haustein, S.; and Hunecke, M. (2007). Reduced use of environmentally friendly modes of transportation caused by perceived mobility necessities: An extension of the theory of planned behavior. Journal of Applied Social Psychology, 37(8), 1856-1883. https:// doi.org/10.1111/j.1559-1816.2007.00241.x.

37. Lee, K. I.; and Gould, R. (2012). Predicting congregate meal program participation: Applying the extended theory of planned behavior. International Journal of Hospitality Management, 31(3), 828-836. https://doi.org/10.1016/j.ijhm.2011.09.019.

38. Fornell, C.; and Larcker, D. F. (1981). Evaluating Structural Equation Models with Unobservable Variables and Measurement Error. Journal of Marketing Research, 18(1), 39. https://doi. org/10.2307/3151312.
39. Baumgartner, H.; and Homburg, C. (1996). Applications of structural equation modeling in marketing and consumer research: A review. International Journal of Research in Marketing, 13(2), 139161. https://doi.org/https://doi.org/10.1016/01678116(95)00038-0.

40. Boudreau, M. C.; Gefen, D.; and Straub, D. W. (2001). Validation in information systems research: A state-of-the-art assessment. MIS Quarterly: Management Information Systems, 25(1), 1-16. https:// doi.org/10.2307/3250956.

41. Sheppard, B. H.; Hartwick, J.; and Warshaw, P. R. (1988). The Theory of Reasoned Action: A Meta-Analysis of Past Research with Recommendations for Modifications and Future Research. Journal of Consumer Research, 15(3), 325. https://doi. org/10.1086/209170.

42. Berry, L. L. (1995). Relationship marketing of services-growing interest, emerging perspectives. Journal of the Academy of Marketing Science: Official Publication of the Academy of Marketing Science, 23(4), 236-245. https://doi. org/10.1177/009207039502300402.

43. Nosal, K.; and Starowicz, W. (2015). Evaluation of influence of mobility management instruments implemented in separated areas of the city on the changes in modal split. Archives of Transport, 35(3), 41-52. https://doi.org/10.5604/08669546.1185186.

Paper submitted: 10.06.2020.

Paper accepted: 08.07.2020.

This is an open access article distributed under the CC BY 4.0 terms and conditions. 